\title{
MEU AMIGO, O LEITOR: MARCAS PARA O LEITOR QUE EU IMAGINO ${ }^{1}$
}

\author{
José Miguel Marinho*
}

O leitor que eu imagino é como o escritor que faz de cada livro a promessa do livro posterior.

Ele sempre termina a leitura de um livro com o sentimento, calmo e voraz, de recomeço.

Ele também nunca lê um livro querendo apenas entender ou decifrar o que o livro quer dizer - ele recria o que o livro nem sabe que é capaz de sugerir.

O leitor que eu imagino é mais criativo quando pergunta e menos quando responde - o livro adora ser eternamente uma indagação.

O leitor que eu imagino nunca tem intenções muito objetivas, ou tem desde que elas não suplantem as tensões e atenções para aquilo que ele não espera e é pura surpresa - a página melhor de um livro.

Ele também nunca sabe e nem tem interesse de saber quantos livros leu na vida porque, para o leitor que eu imagino, cada livro que ele leu pelo desfrute do prazer é tanto e cada leitura de cada livro são tantos livros dentro de um livro só, que é impossível até imaginar.

Mas ele sabe muito bem que, por pior que seja um livro, pela própria natureza do livro que impõe ao leitor uma atenção e um interesse especial, a vida seria sempre menos do que ela é, sem o livro.

O leitor que eu imagino quer que o livro seja ele, o próprio leitor, e escreve nas beiradas da página o que o livro quis dizer e sobretudo o que não quis dizer - este leitor que eu imagino não tem escrúpulos e muito menos medo de rabiscar o livro para poder assim ficar e existir dentro do livro e fazer de uma palavra, de uma frase, de uma página, ao menos uma parte do seu modo de ser.

O leitor que eu imagino lê nos livros as situações mais conhecidas por ele sempre com olhos de primeira vez - por isso mesmo ele chama sempre as palavras de um livro de "palavras de revelação".

Quando está lendo, ele fica sempre à distância de meio braço do livro para ficar mais dentro dele.

\footnotetext{
${ }^{1}$ Encarte do livro, recentemente publicado pela Editora Biruta, A convite das palavras - motivações para ler, escrever e criar.

* Sou professor de Literatura Brasileira e escritor e, "à parte isso, tenho em mim a memória alegremente assimilada de ter feito parte da comissão de publicação da 'Linha d'Água', lá longe, nos anos de 1989 e 90".
} 
Ele, o leitor que eu imagino, amplia, alarga, expande o ego e ganha mais espaço para acolher e hospedar cada vez mais personagens e gente dentro dele e igualmente se tornar cada vez mais "solidário", depois de cada livro que lê.

Este leitor que eu imagino, não poucas vezes, lê, relê, interrompe a leitura e esquece voluntariamente o livro que tem nas mãos, vivendo a plenitude "provisória" de esquecer o livro, para poder imaginar e sentir saudade dos livros que ainda não leu.

Em alguma parte ou em grande parte do livro, o leitor sabe ou imagina saber, com rara e sensível profundidade, o que o escritor escreveu por rara intuição.

Ele interrompe mais uma vez a leitura, mesmo quando ela é inadiável, pelo prazer de fingir que o livro não existe por um momento e, de repente, poder lembrar que o livro é de verdade e ele, o leitor, pode voltar a ser feliz.

O leitor que eu imagino é obstinado por livros, sobretudo pelos livros que ainda não existem e mais ainda por aqueles livros que parecem que nunca vão existir e, além de toda esta obsessão, tem verdadeira adoração pelos livros dos outros, justamente por aqueles que não são os seus.

O leitor que eu imagino nunca é capaz de saber o momento exato em que abriu e iniciou a leitura de qualquer livro - ele precede e pressupõe a história de um livro antes de começar a ler.

Ele é generoso e exercita voluntaria e voluntariosamente a humildade de buscar nos livros o desconhecido e, mesmo conhecendo a realidade mais familiar de um determinado livro, faz questão de tramar um diálogo com ela, como realidade que nunca viveu.

Ao menos muitas vezes ou quase sempre na vida do leitor que eu imagino, ele pede, compra, empresta e até rouba livros sabendo muito bem que ele não vai ter tempo o bastante para ler todos os livros que tem.

Ele vive - e como vive - todos os personagens possíveis e impossíveis na real fantasia dele e na fantasia real dos livros, porque também sabe e lamenta não ter tempo ao menos suficiente para viver e acolher na sua vida a vida deles. Esta é a marca mais humanamente política do leitor que eu imagino.

Este mesmo leitor sabe como ninguém que, se ler não salva, não ler salva menos ainda, às vezes não salva nunca.

Ele lê devagar, senta e lê muito devagar, vive as palavras vagarosamente, mesmo quando a virada da página é mais rápida que o pensamento ávido do que virá depois.

Ele também nunca teve ou terá um autor predileto - ele pode sim ter a predileção por um único escritor.

Cada leitor que eu imagino conhece a infelicidade de perto e até se oferece à experiência de ser infeliz, porque carrega sempre com ele uma bagagem que não oferece o menor perigo de extravio: a certeza de ter simplesmente a felicidade de ler sempre e para sempre, porque ler não acaba nunca, ler ele pode sempre. 
É preciso saber atribuir sentidos às palavras, criar sentidos ou até mesmo inventar os sentidos de um livro para ser o leitor que eu imagino, escrevendo e recriando o livro na sua solidão povoada de gente ou junto com o autor do livro que é seu.

Ele acredita no livro sempre desconfiando - afinal, livro algum é absolutamente fiel às palavras que ele mesmo escreve, seja este livro de que gênero for.

E ele brinca seriamente com as palavras porque ler é puríssimo prazer e faz sonhar nas palavras os sonhos mais reais de todos os leitores.

É destino e missão do leitor que eu imagino aprender a escutar as palavras e as ideias e os silêncios de um livro, sem que ele, o livro, faça o menor apelo para ser ouvido pelo leitor - o livro não faz coisa alguma, o livro apenas é.

É igualmente necessário e urgente saber subverter e inverter as palavras de um livro, armar ludicamente uma confusão de sentidos por vários dias para poder ler, num certo dia, o livro com um suposto sentido de exatidão.

É da enseada mais presente do leitor que eu imagino a palavra que ilumina a realidade e cabe a ele, o leitor, fazer emergir dela, a palavra, o dom de clarear, mas com aquela sabedoria de que não é abrindo mão de todas as sombras do imaginário das palavras que se alcança o melhor foco de luz do seu poder de imaginação.

O leitor que eu imagino é todos os dias e a vida inteira um leitor, ainda que seja o leitor de um livro só ou passe temporadas infinitas sem reviver a experiência imperdível de ler de fato, ancorado como ele permanece nos portos de passagem da memória e da imaginação.

O leitor que eu imagino dá oportunidade ou hospedagem de leitura a todo e qualquer escritor num gesto de atração e recusa, para ser quase definitivamente implacável com os livros que rejeita e solidariamente acolhedor com os livros que estão destinados a ficar com ele.

O leitor que eu imagino só eventualmente, ou por necessidade de sobrevivência, busca o conhecimento utilitário ou pragmático dos livros, mas nunca, jamais, em tempo algum abre mão da leitura como uma das experiências mais felizes de ter um livro nas mãos e mais a expectativa e a vivência circunstancial de ler.

Para cada leitor que eu imagino existe um livro escrito especialmente para ele, igual a um amor predestinado, ainda que este encontro viva somente no imaginário de quem lê como quem ama e ama como quem lê.

O leitor que eu imagino é o personagem principal da história mais incrível que alguém jamais escreveu, mas que parece tão possível para ele como dobrar uma esquina heroicamente, naquele ponto limiar em que viver é uma promessa e o livro existe para fazer viver mais, ao menos um pouco mais ou eternamente, o que é matéria viva e não pode nunca morrer. 